\title{
Permanent Black Immigrants' Experiences of Working in Ontario
}

by

\section{Kimberly Coleman-Bryan, GWS, BSW}

\author{
An MRP \\ Presented to Ryerson University \\ In partial fulfillment of the \\ requirements for the degree of \\ Master of Social Work \\ in the Program of \\ Social Work
}

Mississauga of the New Credit's Traditional Territory, Turtle Island Toronto, Ontario, Canada, (C) Kimberly Coleman-Bryan, 2020 


\section{AUTHOR'S DECLARATION FOR ELECTRONIC SUBMISSION OF A MRP}

I hereby declare that I am the sole author of this MRP. This is a true copy of the MRP, including any required final revisions.

I authorize Ryerson University to lend this MRP to other institutions or individuals for the purpose of scholarly research

I further authorize Ryerson University to reproduce this MRP by photocopying or by other means, in total or in part, at the request of other institutions or individuals for the purpose of scholarly research.

I understand that my MRP may be made electronically available to the public. 


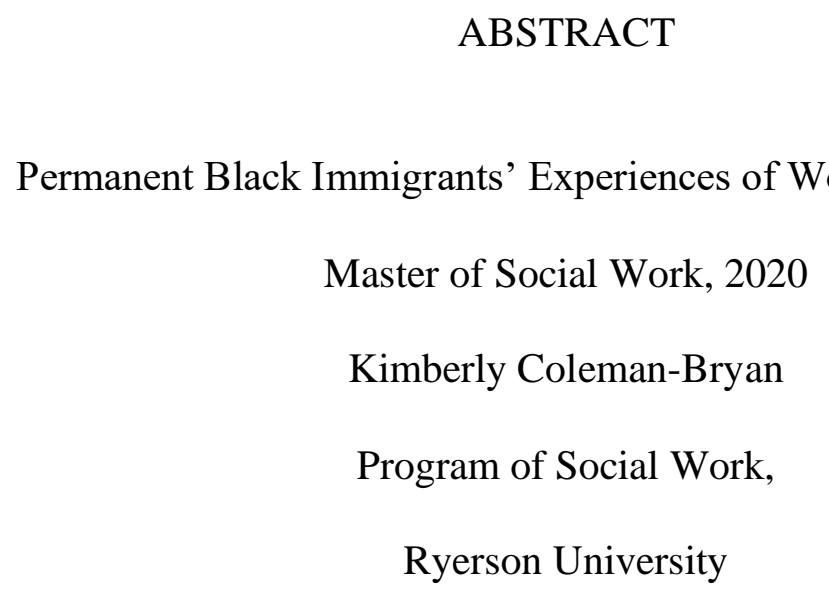

This Major Research Paper is a qualitative study that utilizes a narrative approach through an anti-Black racism lens to investigate the cultural, historical, political and socioeconomic factors that influences the career advancement and employment journey for Black immigrants in Ontario, specifically those from the Caribbean. This study follows the employment journey of two adults of African descent in Ontario. Through their stories, the two participants detail their experiences with subtle systemic racism and resulting precarious employment. Other common themes that emerged amongst the participants were low income status, blocked career advancement opportunities, maintaining multiple jobs, lack of training specifically for Black immigrant adults, and low wage employment. The paper concludes by highlighting the importance of changing policies and structures in order to remove the barriers to stable employment and career advancement faced by people of African descent.

Keywords: Anti-Black Racism, Narrative, Ontario, African, Caribbean, Black, Employment Stability, Systemic and Policy 


\section{ACKNOWLEDGEMENT OF LAND}

Ryerson's Land Acknowledgment

"Toronto is in the 'Dish with One Spoon Territory'. The Dish with One Spoon is a treaty between the Anishinaabe, Mississaugas and Haudenosaunee that bound them to share the territory and protect the land. Subsequent Indigenous Nations and peoples, Europeans and all newcomers have been invited into this treaty in the spirit of peace, friendship and respect."

"Ubuntu,"......... "I am because we are,"

\section{ACKNOWLEDGMENT OF THOSE BEFORE ME}

To my Ancestors, thank you for the sacrifices, trials, fights and work you've done to get us (me) where I we are today; I hope that I have at least begun to make you proud!; and as I hold onto the Mantle of Change steady walking, and increasing my pace to run and eventually pass it on to the Moms, Dads, Aunties, Uncles, Cousin, Brothers, Sisters, Nieces and Nephews that will arise to receive the Mantle of change for future generations; Thank You!! 


\section{THANK YOU}

What an incredible journey to have been on with such an amazing team of supports. Thank you, Gordon Pon, Jennifer Poole, May Freidman, Purnima George, Renee Ferguson, Shane Young, Notisha Massaquoi, Bree Coleman, Milene Santos Costa and Funke Oba for all the theory, life experience, inspiration, editing and support you provided me on this MSW journey; Thank You!!!

Gordon, for the many encouragements throughout this journey. Your calmness was an inspiration that guided me to continually look within; Thank You!!

Jennifer, for always being expectant of an amazing outcome. Your spirit has been a constant reminder of the many Angels on earth disguised as humans; Thank You!!

Duke and Jordon, for the many experiences, laughter and hardships shared with me for this Major Research Paper; your willingness to let me in as you walk me through your past and current employment journey; Thank You!!!

Romeo Rodney, for before I knew myself and sticking with me while I figured "me" out while you were figuring yourself out; Thank You!!!

David Grant, for your amazing editing talents and your work on "Understanding the Complexities and Health Implications of Black Fatherhood in Toronto"; Thank You!!!

Keturah Alberga; Douglas Medder; Felix Ayigbe, the many conversations and encouragements filled with laughter that you brought to me through this journey and during this process due to your authenticity, calmness, patience and awesomeness. You unknowingly assisted me through this process and with gratefulness I say, Thank You!!! 


\section{MY ANCHORS}

Wow! Right! We did it!

My anchors, Everton Bryan, Cemmor Black, Stacy Smith, Maxi Smith, Dontée Black and my three J's and my two Z's; without you this dream would not have been possible to begin or complete.

Everton, (Randy) my other side, your dreams, your passions and the way you reach for them with no apology; I wish I could be you more often; Thank You!!!

Stacy, Max and A-Dontee you stood in solidarity with Mom continuously praying, encouraging and supporting me to reach deeper within and past myself in order to aggressively but humbly produce and embrace what a portion of the Most High has in store for us. Thank You!!

To my Cubs, Jai, Jae, Jay, Zi, and Za for the many hugs, kisses and glasses of water you have ambushed me with and for the many days and nights you rested quietly so that I could accomplish this dream with you; a dream that was ignited by Cutie and fueled by my Passion for Change; Thank You!! 


\title{
DEDICATION
}

This paper is dedicated to Cemmor (Cutie) and Everine, invisible soldiers who sacrificed their lives for their families, worked tirelessly for low wages; with little opportunity for advancement to offer economic and financial security to future warriors who'll also carry the Mantle of Change to partake in the creation of a world, a future where Blacks can stand whole, strong, proud and prosperous. Thank you for never giving up on your visions and dreams and for showing me the importance of fulfilling your role in carrying the Mantle of Change. Without your love, sacrifice, prayers, tears and laughter this would not have been a though much less a dream coming to pass. \\ It has been a journey; I've travelled a long way, \\ Yet still I feel like no progress is made, \\ I travelled from mental bondage, to freedom of mind, \\ Relinquishing all pain and hurt, that I've gathered over time, \\ Still every now and again I stop and think, \\ How different life would be if she were still in it, \\ I know I would smile more, and I would laugh longer... \\ I'd run and say "Hi" when I see her \\ Instead of crying because I thought it was her, \\ I would not have to dedicate life and ways, \\ If she was here to see it, if she could still say go, you go girl, \\ She was the one that fought for me, \\ Who helped me to fight for myself,
}


I was dumb and young, she was older and wiser, I let her down over and over,

I wanted to be me, she wanted me to be more,

She fought, until we fought, and now I fight

Fight to hold on to the words; the embrace that changed my life,

At that moment I stopped, Oh I remember her tears,

How they gathered in a jar of hope for me,

I made up my mind to change, no more would I play

Play the slave to life, all wrapped up in bondage,

Not much is different, but it won't be that way for long,

She can't touch me now, but she touched me then

And I will use it all up, yes that touch I mean,

I know that I am nowhere yet, but soon I will be,

I have travelled a very long way,

And truly it has been a painfully long journey,

Maybe that's why I can't name it.

$* * *$ Mercury $2010 * *$ 


\section{TABLE OF CONTENTS}

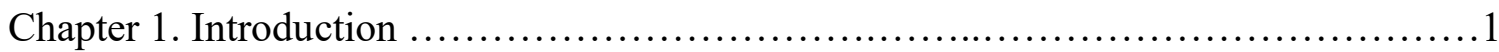

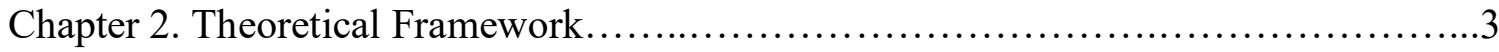

Chapter 3. Literature Review................................................6

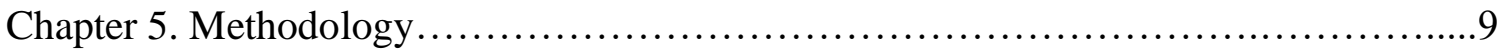

Chapter 6. Recruitment and Sampling ......................................... 11

Chapter 7. Data Collection, Analysis and Translation............................. 11

Chapter 8. Overview of Participant Narratives.....................................12

Chapter 9. Participant Narratives..............................................13

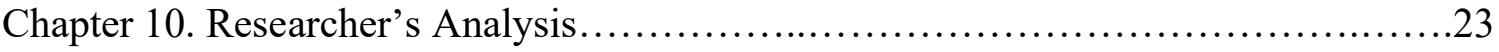

Chapter 11. Conclusion......................................................26

References................................................................. 28

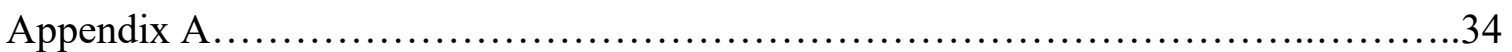

Appendix B...............................................................

Appendix C................................................................. 40 


\section{INTRODUCTION}

Canada's “introduction of the Domestic Workers Scheme in 1955” (Burt et al., 2016, p. 4), intrigued many Afro-Jamaican women and this immigration scheme sparked a chain migration epoch (Burt et al., 2016). Afro-Jamaican women seized the opportunity and migrated from Jamaica to Canada as domestic workers in search for anticipated economic opulence while concurrently working to sponsor their children and other family members (Burt et al., 2016). Prior to 1981, more than half of the Black population were born in either Jamaica or Haiti (Statistics Canada, 2016). Currently, Statistics Canada notes that over 3.5 percent of the population is Black with 52 percent of the overall Black population being recent immigrants predominately residing in Ontario (Statistics Canada, 2016). Within the Black population, AfroCaribbean folks are the most common cultural groups in Canada (Statistics Canada, 2016). Despite the small percentage of the population that Black people make up, in 2016, Statistics Canada reported that Black folks, despite their willingness to work, have one of the highest unemployment rates in Canada at 71 percent, making their unemployment rate higher than any other non-racialized group (Block \& Galabuzi, 2018). Black and racialized women continue to face more employment barriers than men and Block and Galabuzi (2018) note that not much has changed to remove barriers in the labour market for Black people.

Throughout my life, I have personally witnessed the trials and tribulations within my family that come with being not only an immigrant, but a Black immigrant. I was born in Jamaica and I was raised in Canada. I immigrated to this country as a pre-schooler to meet my grandmother who initially came here as a care provider for an established English family. When she was financially stable enough to send for my mother back home in Jamaica, my grandmother 
sponsored my mother to come to Canada. Together, my mother and grandmother worked diligently to bring our entire family to this land which presented itself as the land of opportunity and economic opulence. Despite the academic qualifications of some of my family members back in Jamaica and good work ethic, they were rarely afforded opportunities for career advancement or stable work in Canada. Hence, my immediate and extended family had to work multiple jobs in attempts to achieve the goal of a more positive, financially, and socially stable life for my family contrasting their impoverished life back in Jamaica. Despite their tireless work ethic and sacrifices, this "Canadian dream" gradually became farther out of reach until reaching a point where it practically became a fantasy. A promotion or stable employment was nonexistent in my house; the privilege to rest or take a sick-day was out of the question and to even receive opportunities to receive training tailored towards career advancement were neither made available nor attainable. Concurrently, I also experienced the difficulties of obtaining and maintaining stable employment in Ontario as a youth, young adult, and mature adult. It pained me to hear remarks and stereotypes suggesting that Black people in Canada are welfare dependent considering our over 200 years of forceful participation in free, arduous labor and another 200 years of subtle forced participation in low-wage labour.

These experiences inspired me to research this phenomenon of blocked economic opportunities for Black immigrants. It also inspired my determination to play a role in dismantling these barriers for future generations. I do acknowledge that I possess privilege including being a Black woman with lighter skin, not possessing a strong Jamaican accent, completing post-secondary education and obtaining stable employment at a youth mental health agency. Notwithstanding this privilege, my experience as an Afro-Jamaican immigrant now 
residing in Ontario in combination with my first-hand experience witnessing other generations of migrants and settlers before me labour on this land will provide me insider-status in pursuing this topic. This insider-status allows me to navigate between the two worlds (Humphrey, 2007) as privileged and under privileged as I complete this research paper.

\section{THEORETICAL FRAMEWORK}

I define racism as a system of power that disadvantages and deems certain groups of people as inferior while benefitting and deeming other groups as superior. Anti-Black racism however uniquely disadvantages people of African descent because it is the practice of specific attitudes and notions, in addition to prejudicial, systematic, and discriminatory practices that target Black people. This study will analyze the research through an anti-Black lens and I will draw on material from the Toronto Action Plan to Confronting Anti-Black Racism to demonstrate the action steps the city is taking to address the employment barriers faced by Black people.

Anti-Black racism operates in our daily interactions, also recognized as micro level issues, to being embedded at the institutional also known as the macro level. The City of Toronto created the action plan to address these various issues ranging from the micro to the macro level affecting people of African Descent. In 2016, The City of Toronto created a 5-year action plan beginning in 2018-2022 to address the multiple issues that Black women and men, including youth, face in Toronto (City of Toronto 2019). People of African descent are overrepresented in the criminal justice, child welfare and mental health system despite making up a small 
percentage of Toronto and Ontario's overall population (City of Toronto, 2019). This harsh reality can be attributed to the fact that,

...44 percent of Black children live in poverty compared to 15 per cent of non-racialized children... 32 per cent of children in the care of the Children's Aid Society of Toronto are Black, three and half times their representation in the overall population... Black students become "early leavers" of high school at higher rates - 23 per cent compared to 12 per cent of white students... Torontonians of African descent have an unemployment rate of 12 per cent, nearly two times the provincial rate. (City of Toronto, 2019)

Contrary to racist belief, there is no genetic trait that makes Black people more prone to criminality, mental instability or intellectual ineptness, rather racist environmental, institutional and societal practices have shaped the identity of Black people and dictated how they should be treated. The action plan demonstrates that the City of Toronto has reached a point where they recognize that the longstanding and unresolved effects of colonization and the enslavement of African people has had a devastating effect on the poor outcomes of Black people and the normalized racist thinking of non-Black people and the Canadian White supremacist government including its institutions, policies, and procedures in the Canadian government. Hence the City of Toronto is now in a position where they seek to rectify past wrongs against Black people and address the inequities that are experienced by people of African descent (City of Toronto, 2019). To work towards this goal, their aim is to create initiatives to address each of the five main areas of concern: employment and entrepreneurship, supporting Black not-for-profit organizations, 
anti-Black racism in workplace institutions, children and youth development, and anti-Black racism in the customer service industry (City of Toronto, 2019).

Through an anti-Black racism lens, I will be able to understand how Black adults who immigrate from majority Black countries such as those in the Caribbean and Africa are perceived when they arrive. What many people do not realize is that when Black people arrive from these majority Black countries, they may know intellectually that they are Black but instead identify with their nationality i.e. Jamaican, Ghanaian, Congolese. What happens when they arrive in Canada is that no longer are their nationalities the differing factor from their other Black counterparts; rather they are shuffled into a category of "Blackness" where they are now faced with the fact that their "Black" identity is equated with inferiority, laziness, trouble and violence. Anti-Black racism theory demonstrates to us that these lingering stereotypes and notions about Black immigrants have persisted since the days of slavery where Black people were overworked and underpaid.

What makes matters worse, for example as it relates to the Domestics Scheme in 1955, is that even with their academic qualifications from their native countries, Black people, specifically Black women, were only permitted into Canada on the basis of them being domestic servants (Barber, 2006). What anti-Black racism shows us is that Black people, their academic qualifications from their native country and their intellectuality are still deemed inferior to that of the White supremacist government system and are replaced with their physical ability to perform arduous labour for low wage pay. What this lens also demonstrates is that Black people being underemployed and not provided or informed about career advancement opportunities keeps 
them and their families impoverished and marginalized. This lens will be able to show me the various employment barriers that Black people experience upon arrival in Canada and throughout the course of theirs and their families' lives.

This research paper will begin with a review of the literature, the methodology used, followed by stories shared by the participant and my analysis of the stories. I will conclude with my recommendations to inform anti-oppressive practice, employment, and immigration policies. Concerning terminology, the term Afro-Caribbean will be used to signify a connection back to their African roots but displacement to the Caribbean. I will use the term Black and African descent to signify a universal identity despite geographical differences. Lastly, when using the terms African Diaspora, this will exclude Arabs who also reside in parts of Africa and will strictly pertain to those whom are traditionally African.

\section{LITERATURE REVIEW}

The literature reviewed for this research study came from various databases: Ryerson University Library - Social Work Abstract, Sociological Abstract, Social Services Abstract, ProQuest Research Library, Google Scholar Database, City of Toronto Database, and Statistics Canada and Census Database. The search terms used for this research were: employment, Black employment rates, Black immigrants, career advancement for Blacks, Black adult employment, Employment in Ontario The keywords used were: Blacks, African, Caribbean, low income, immigrant, newcomer, middle class, Ontario, Toronto, barriers, opportunities, adults, seniors, income, and rates. When searching these keywords and terms it was noticeable that Black youth had more data recovered for employment than immigrant adults who are required to work and 
provide overall needs for the children, youth, and elders in Ontario. The prominent themes from the literature reviewed were the following: poverty, precarious and underemployment, and subtle systemic racism.

\section{Anti-Black Racism and Poverty}

As noted above, Black people continue to suffer from high poverty rates despite making up a small fraction of the overall Ontario population. One of the major factors contributing to this issue is the high unemployment rate amongst people of African descent in Toronto (City of Toronto, 2019). Naturally, being new to a country as an immigrant or refugee makes one more susceptible to poverty, especially when entering into a country without academic qualifications or skills or with these same qualifications and skills that Canada does not recognize. Navigating a new country and province is difficult enough for any immigrant or refugee but when this challenge is compounded with the violence against one's Blackness, it inherently leads to a poorer quality of life for people of African descent (McDonald, 1998; O'Connell, 2013; Picot, 2004).

Poverty in general is not the main challenge as some Afro Caribbean peoples were living in impoverished situations in their native country, rather the disparity of poverty coupled with social isolation and racism is the new challenge they have to experience (Howard, 2019; Kumsa et al., 2014; Reitz, 2007). A significant factor contributing to this overwhelming percentage of poor Black families is the legacy of slavery, colonization and racism in Canada that has stripped people of African descent of their humanness and subjected them to the bottom of society (Frank, 2013; Greenberg, 2016; Ng, 2020). Poverty in combination with racism places added 
stress on families and worsens the overall health of Black people, especially those who are immigrants and refugees over time (Block, 2018; Clarke, 2015; McDonald, 1997; 1998; Phillips \& Pon, 2018; Powell, 2003).

\section{Precarious and Underemployment}

Literature notes that Black immigrants from the Caribbean in Canada continue to be overworked but underpaid, despite many of them possessing academic qualifications from their native country (Block, 2018; Clarke, 2015; McDonald, 1997; 1998; Phillips, 2018; Powell, 2003). Research notes that many Black immigrants strive to move beyond seasonal, factory and low wage employment but find themselves facing a glass ceiling (Humphrey, 2007; Maynard, 2017; Maiter, 2017; Meerai et al., 2016; Patterson, 1982). Some scholars argue that the legacy of slavery in Canada influences the current context and comfortableness of organizations justifying Black immigrants being underemployed and underpaid (Frank, 2013; Greenberg, 2016; Ng, 2020). Additionally, the literature also highlights that Black immigrants are more likely to experience precarious employment, all of which contributes to perpetuated poverty $(\mathrm{Ng}, 2020$; Frank, 2013; Greenberg, 2016). Furthermore, the City of Toronto (2019) notes that the effects that these barriers to employment and lack of stable income can cause is high involvement in government social assistance programs and systems and remaining in entrenched poverty.

\section{Subtle systemic Anti-Black Racism}

Prior to 1955, racism was more overt as the White supremacist Canadian government was blatantly racist about their ideologies surrounding Black people leading to their overt discriminatory practices of prohibiting Black people entry into Canada (Burt et al., 2016). Since 
then, although there are still incidences of overt racism in Canada in various provinces with high concentrations of Black people like Ontario, anti-Black racism has become more covert (Hacket, 2019; Phillips \& Pon, 2018; Kumsa et al., 2014; Ray et al., 2017). Literature illustrates that Canada's systemic racist acts are more subtle demonstrated by Black people's overrepresentation in various sectors such as the unemployment and child welfare sector (Baskin, 2016; Phillips \& Pon, 2018; Pon, 2004). In other words, while it may not be acceptable or legal to openly discriminate against Black people when it comes to employment, White supremacy strategically will state that one's academic qualifications from their native country are not recognized, despite their experience and the strong similarities in practices.

My research study intends to fill in this research gap by exploring the employment journey of two participants of African descent and how subtle anti-Black racism is in Ontario in perpetuating the under and precarious employment and longstanding poverty epidemic within the Black community. This gap will be best achieved through a narrative approach as it will allow the participants to freely express themselves and bring their lived experiences to the forefront. This study attempts to answer the following research question: What are the employment experiences of Black immigrants in Ontario in relation to their experience back in their native country?

\section{METHODOLOGY}

The research study was completed through a narrative approach to best capture the voices of the participants in this study. Through narratives, participants are able to share their wisdom, knowledge, and experiences when engaging with researcher. Narratives through the art of oral 
story-telling have also always been a part of traditional African and African Diaspora cultures such as those whom are Afro-Caribbean (Greenidge \& Daire, 2010). According to Chase (2005) the narrative approach allows qualitative data to emerge that can provide in-depth meaning and understanding of the lives of participants. Chase (2005) explains that looking at people's stories through narrative has two principles; one being that through the sharing of one's story they can express their self, experiences, and place meaning on what is being shared through their stories; and the second being that all stories no matter how "unique" are social in character (Chase, 2005). Hence, having the participants share their stories of their employment journey will not only adhere to traditional Afro-Caribbean culture, but will also provide a voice to them amidst a society that has vowed to silence the voices of people of African descent.

These narratives would also be known as "counter-stories" are an important concept in the Critical Race Theory (CRT) framework, which are stories that counter the dominant discourses surrounding marginalized peoples' experiences (Solorzano \& Yosso, 2002). Some of the dominant narratives that influence institutions and individuals' perceptions of immigrants of the African Diaspora as noted earlier are that they are unintelligent, and only suitable for labor rather than managerial positions. Anti-Black racism being my theoretical framework, coincides with the importance of counter-stories being that it places race at the focal point and challenges hegemonic stories about racial privilege and stereotypes that been associated with marginalized ethnic groups (Solorzano \& Yosso, 2002). Counter-stories bring the readers into the world of the story-tellers to better understand the realities of those whom continue to be the victims of racism (Solorzano \& Yosso, 2002). 
The narratives told in this research study will challenge the supposed equitable employment sector for immigrants, particularly those who are Black. The participants' stories will challenge the life of Black immigrants as it relates to their family dynamic, their work ethic, and career aspirations. Lastly, this study will shed light on the overt and covert racist practices that take place against Black people upon arriving in Canada regarding what opportunities are and are not available to them.

\section{RECRUITMENT AND SAMPLING METHODS}

The recruitment process was executed through flyers (See Appendix A), distributed through an email asking for recipients to share with their networks. For the purpose of recruitment, participants were also sought through community agencies and members who were asked if they knew anyone who would be interested in sharing their employment journey with the researcher. The participants were given explanations about the consent form and they both signed it (See Appendix B). This research used a criterion sampling method, a method that has a pre-established set of criteria that the participants must meet in order to be involved in the study (Ciupa, 2006).

\section{DATA COLLECTION, ANALYSIS AND TRANSLATION}

Interviews were semi-structured, which enabled participants to share more than what was asked and to share stories that connected to and broadened the main research question. Some of the interview questions included: What are your experiences with each position worked in Ontario? What types of career development training have your employers offered you? Have you experienced any barriers to employment or career advancement? (See Appendix C). Pseudonyms 
were used to protect the identity of each participant. The data collected for the research paper was audio recorded on a separate device during the interview that was conducted via phone and/or Zoom. Each interview took approximately an hour and thirty minutes in length after breaks and self-care were included. The data was analyzed through the narrative approach and followed thematic and structural format. All data collected were file safe, locked with a key, and accessible only to the interviewer.

\section{OVERVIEW OF PARTICIPANTS' NARRATIVES}

Jordon is a single Afro-Caribbean woman from Guyana in her early thirties who completed her post-secondary education in Ontario. When Jordon moved to Ontario nine years ago, she resided in North York where she still currently lives with her parents. Jordon moved from Guyana with her mother who was approved as a skilled worker, her father, and her siblings in search of employment opportunities and to obtain employment in their field of study which was achieved abroad. Jordon is currently employed and working one job; however, she is seeking opportunities to advance her career.

Duke is an Afro-Jamaican man in his early thirties who completed his high school education in his native country of Jamaica. Duke arrived in Ontario three years ago after multiple visits to the country. Duke came to Canada by himself and he now resides in the east end of the city. Duke moved from Jamaica to pursue career opportunities and obtain his diploma/degree in his field of work. Duke is currently employed and works three different jobs. Duke has been seeking opportunities to start his own business aspiring to be able to pay for his education and have a better life. Duke has one dependant. 


\section{PARTICIPANTS' NARRATIVES}

Jordon's Arrival Story

Jordon engaged in a work-study program in the medical field at the age of sixteen and completed high school in Guyana. After graduating high school, she immigrated to Ontario, Canada in her twenties with her brothers and parents. Jordon shared that two of her brothers and her parents were working in their field prior to moving to Ontario. She explained that her and her younger brother had just finished school and she was still in medical school because "that's like the culture there...I was at a hospital working in the clerical department" for the work study. When Jordon and her family arrived in Toronto, her father and her brother's medical education credentials from Guyana were no longer valid in Canada and they were no longer able to practice in their field. Contrarily, Jordon explained that her mother was approved for a skilled workers program and eventually received a career that was equivalent to the one that she had in Guyana. Jordon describes her mother receiving her career position and salary as a financial analyst as "a bit of luck" due to another Caribbean person hiring her because he was "sympathetic to her plight". When Jordon described the process for obtaining employment in Ontario as a new immigrant, she explained that her father and her brother both settled for low paying jobs that were out of their field. For instance, back in Guyana, Jordon's father was a manager for an insurance company, yet when he arrived in Canada, he could only obtain a job as a car salesman. Jordon explains that her brother experienced the same rejection of his credentials as a doctor back in Guyana and decided to pursue higher education to "get a marketable job" in Ontario.

Throughout the nine years that Jordon has resided in Ontario, she has worked for seven

years holding various low paying jobs, sometimes three at a time while pursuing post-secondary 
education. Jordon shared that at one of her places of work, she was looking for a wage increase through a promotion because she noticed that she was being overworked by always receiving more challenging work and doing "double" the work by picking up the slack of other staff members. Concurrently, Jordon and her family were mourning the loss of various family members to whom they provided family support abroad. While still grieving the loss of her grandmother, Jordon shared that she told her manager that she would be taking some time off to further mourn her grandmother's death and would not be attending work the next day. However, her manager was neither empathetic nor supportive of her decision to take time off:

Don't think he was listening to me, I don't think he heard me, I don't, I don't know. He scheduled me for work and I was already having a rough day because again the passing of my family and the other staff members weren't doing what they're supposed to be doing... and he obviously wasn't listening to me and I just said I quit, that's what happened.

\section{Current Experience}

Jordon currently works as a medical technologist and shared that each position at her workplace is filled by someone who has the specific requirements for the field of work. Hence, everyone in that position, ideally, is on an equal-level playing field when it comes to advancements, raises or promotions. Yet, Jordon shares that her current job has very little opportunity for career advancement due to advancement being based on seniority. Additionally, she notices that individuals who hold seniority within the organization are rarely issued consequences when it comes to inexcusable behaviours at work. She further explained that with 
the exception of one job, most of her jobs did not operate on a merit-based system, rather it was based solely on seniority.

While working at one of her jobs, Jordon noticed that she was receiving all the individuals that as she explained were "...the problem ones":

Because like I'm pretty chill and I got, like for example, like one person she was having problems with her on her side and instead of firing her they sent her to me and Anna didn't tell me why they sent her so...I was like, okay, I'll work with you...I realized she just needs some extra guidance, but I'm like if you're a manager and you know what the problem was first you need to tell me about it and instead of them trying to fix what was her individual issue to just pawn her off at someone else until her contracts finished instead of dealing with it.

During this job experience Jordon realized that there was no training to manage the high level of support some of the youth she worked with at this community-based agency needed. She explained that because of the needs of these Black youth, they would often be "hard to deal with; youth got pawned off to the people that looked like them" and most of the time they were sent to her. It was in this position that Jordon was approached about an employment internship opportunity with the partnering company.

Jordon expressed feeling disappointed when it never materialized; someone else was hired over her. Jordon also noticed that it appeared that the well-known and well-funded organization that employed her to work with the partnering company, was blocking employees, 
most of whom are of Afro- Caribbean descent, from seeing and applying to other positions within the company:

I also knew about that too, that they had blocked us...they had blocked us from actually going onto the portal to see other jobs...so I do remember that happening....so if we were interested in going to somewhere else they blocked us and they had basically just kept us where they wanted us to be. So, it was either you do what you want to do or just leave the company kind of a bit. So, there is no opportunity for career advancement, even though they knew you were seeking it. So, they have blocked it...they blocked everyone, everyone was blocked. Yeah. So even if, thing is, if you had an interest they would not know because they blocked you from the start.

Jordon shared that since she has been in Canada, notwithstanding her university level education, she has only been able to secure precarious jobs that pay minimum wage and have no room for advancement or growth. She describes that in her various career ventures, she noticed that more white folks would apply and get into the work study programs rather than Black people. She also noticed that at places where she was employed outside of school to work with youth in low income neighbourhoods, most of the staff and youth were of Afro-Caribbean descent. In the latter places of work, she was also payed minimum wage with a possibility of being considered for a more permanent position and higher pay. Jordon explained that for minimum wage, she was handling high risk situations, without any adequate training. Despite her hard work, perseverance, and success through these trials, she was still overlooked for the career advancement opportunities. Jordon expressed her fight to obtain higher education to secure a 
career in her field with fair wage and advancement opportunities: "I feel like I'm really digging a hole, like I'm slowly getting out of a hole like very slowly. I don't know..."

Jordon expressed her frustration with the system for not providing acceptable employment supports for adults:

“...because a lot of the service that are available to persons of my background and so forth would have been when they were in high school going into University, not being in University or have left University. So, it's kind of like you're doing this on your own...I came to Canada older. Yeah, so it's kind of daunting because you're like doing this on your own and there is limited programs you notice and services that will give you the same support that the youth would get... a lot of the programs, a lot of them are here for students that are in high school going into University.

\section{Recommendation}

Jordon expressed her opinions about what she would have liked to have seen for herself and her family when they arrived in Ontario. She also provided recommendations around what could be done now to support immigrants of Afro-Caribbean descent in the Canadian employment system. She expressed the following:

A lot of skilled workers have been coming here over the years again. They can't get back into their field. Um, I think I feel they could do a better job of that. If you have doctors and lawyers and engineers coming from other countries, they should be able to, even if they're being offered upgrades and so forth. They should be offered upgrades ... or being given resources to be able to get those upgrades that would financially unburden them...I 
think they need to be given resources or programs to at least...get the guidance of becoming Canadian qualified. Come here as a doctor but end up as a taxi driver or working at a factory because they cannot (sigh) you don't have any government support to be able to transition. And that can be done through programs, services, grants, mentorship. Just like how it comes with your welcome packet or welcome to Canada... They should be given things to streamline them as well.

\section{Duke's Arrival Story}

Duke was born and raised in Jamaica where he completed high school and described working, "mostly in cooking... so I wanted a restaurant. I worked for a lot of companies there, until I branched out on my own and started my own business." However, he did not pursue postsecondary education. He arrived in Canada from Jamaica by himself in his late twenties and did not pursue post-secondary education here. He explained that he came to Canada to visit prior to later settling here permanently in 2017. Duke does have family in Canada as well as one dependant. When Duke arrived, he wanted to pursue education in order to obtain a good job in his field but soon realized that he did not have access to the necessary resources. This lack of resources proved to be a barrier to pursue the credentials that could lead to better financial stability. When reflecting on his experience visiting Canada versus living here, he stated "living here now was a total different story".

Duke explained his job history starting from his arrival to Ontario, "I didn't go in the cooking field here...I wanted to give it a break....my mindset, wasn't at cooking. It was like I was hungry for something good to happens. Whatever came my way. I just did it”. The jobs that

came his way as Duke describes were cleaning, packaging or picking jobs. He explains that with 
the cleaning job, he was fortunate to receive this opportunity because the employer was also of Caribbean descent and assisted him in his search for employment.

However, because Duke was unable to obtain better employment or get support with receiving postsecondary education, he felt stuck and often disrespected by his employers. Duke states:

Once when I just came, I tried to approach an education but there was a lot of obstacles in my way. So, I didn't, I didn't go through with it. I just leave it alone. Actually, I couldn't support myself in doing it and I didn't have no formal support... so I had to do everything on my own... because it's very expensive what I want to do, and the government wouldn't have helped you...I was just new here.

\section{Current Experience}

Duke shared that he works at a picking and packaging company. He expressed that he held contract positions in all of his jobs obtained in Ontario and only at this current one was the discussion of a promotion and wage increase ever discussed. Duke has been working for an agency which offers temporary and seasonal contract work at minimum wage regardless of the amount the company outsourcing for employees pay. Duke says,

In terms of jobs, they are open. There are open job and stuff. But you know...They're like contract jobs, lots of contract job. I've never been hired in Canada; it comes up but it never go through. I don't know really know why there are always obstacles in the way...like I've been working in for like one company for like a year and something almost two years and every time this comes up there was always something else, 
someone, someone else get more preference...you're okay with me and everything but every time you should put pen to paper...so I don't know what goes on behind closed doors... it would have been better because most of the jobs I do they go through the agency.

Duke shared that his experience of advancement or wage increase has always been challenging and that he has been made to believe that he would be next but has never achieved it. Duke went on to share that he often loses the position to someone else who has been there for a shorter period than him. He explained that the promotions are supervisory positions and for the time he has been there, no person of African descent has been given that position. He states: “They always get preferred over you. They have the more advantage over you. I don't know but that's what I've noticed."

Duke further explained that almost all the employees where he works are immigrants from another country who have recently arrived in Ontario. He describes a place where everyone sticks to their own ethnic groups and certain individuals will get advanced over others to be supervisors. Duke shares that he has never seen a Black manager since he has started.

Furthermore, he noted that all of his managers in Ontario have always been white. Duke shared that regardless of how many times he has been looked over for wage increase or promotion that he,

“always work properly when your time comes it comes maybe just not your time, but it doesn't affect me in terms of me doing my job...so I just look at it as I have a job. I don't really care about that. My only goal is to get my pay at the end of the week, and I have a 
job; so, I don't make it part of me as much on a whole, maybe it would affect someone else."

Duke explained that he knows some of them offer permanent position for people whose work they value, however, permanent positions are rarely provided because as Duke explains, they would rather let everyone go when its slow than to have permanent staff and have to continue paying them. Duke explained that during his contract position at his current place of employment a pandemic spread across Canada and into Ontario which required him to stop working. As a result, he lost income and was eager to get back to work. However, when he was called back in, Duke says he didn't go. Duke shared that he wants to upgrade himself by re-entering into school but unfortunately the workplace, "they don't provide that kind of support system for anyone to do those kinds of stuff." Duke expressed that at all the temporary contract jobs that he has held in the last three years, the overall understanding was that,

You will always be stuck at one level, especially when you are Black...you know...I mean there's a certain, let's just say you have selected certain amount of people who will always go higher than you, especially when you're Black, and I mean you're always been overlooked...I feel as I said it all comes down to the race and classism...they don't rub it in your face, right, but you could just look at it.

Duke further shared that he does not see white Canadians in the factories where he has worked since his arrival in Ontario. Duke describes that most of the floor workers and employees are new immigrants and on the odd occasion possibly one or two White European Canadians. Duke then said, 
Immigrants and new immigrant people just looking for opportunity and whatever they could grab they just grab it because ... we don't care, we can maneuver our self in any situation at all. So, people will grab, do anything and that's it...the low paying jobs are filled up with more immigrants... company doesn't support you that much; interested to get their bottom line. They don't support you in any way... so I said, well, I realize it is convenient to work for years and then a position of the new really open and you are the last option, you know...best advice for immigrant coming to Canada just educate yourself or like me, you always be stuck in minimum wage system.

\section{Recommendations}

Duke offered many recommendations about how to improve the lives of Black men like himself, who came to Canada from Jamaica, and experienced many hardships and setbacks postmigration. He offered the following: "Open more opportunities, you know, by being more acceptable to people with their situation and the position that they're in...care about people a bit more you know...give them the opportunity as a fair deal... provide training, provide good training".

Duke shared that as a Black employee if a position opens up and he has been working at the company for over a year he was overlooked for the position instead of being trained to fill it:

"It's, I think, that's all convenience to do provide training, if there's a position and there's a person and this person is available to fit that position why not train them to fill the position? ... You know, I mean...so to me...just providing more training and support. You know. Just need more support. 
He shared that having support to get training, upgrading and post-secondary education for AfroCaribbean people who enter Ontario would better their lives and that of their families. He explained,

It could be better, I get in a better paying job ... say for example... I could afford to go to school and take some classes and upgrade myself, right, and still have a job; some companies you don't have time to so that you know what I mean because they don't provide that kind of support system for anyone to do those kinda stuff...they don't."

In the following section, I will analyze the findings in greater detail by drawing upon relevant literature and my own experiences with employment in Ontario.

\section{RESEARCHER'S ANALYSIS}

\section{Subtle Systemic Racism}

Both Jordon and Duke lived in majority Black countries where their skin colour as Black people was not overtly the cause of discrimination or subjection to detriment. Thus, they experienced a culture shock when they came to understand that, as noted earlier, that no longer were their differences dictated by their nationality or geographical differences. Rather, the negative narrative surrounding their Black skin became the principle determinant of how they would be treated.

On different occasions, the participants described conditions where merit-based work played no factor in getting a better paying position. Both Jordon and Duke also shared many 
stories of those who were White predominately held supervisor positions while Black and other ethnic groups held frontline labour positions demonstrating the subtleness of racism.

Both Jordon and Duke tended to blame themselves for their current employment situation; they appeared reluctant to blame the system by consistently referring back to merit and hard-work saying that it will eventually pay off and that returning to school will give them more leverage. Coupled with their challenges in advancing forward, despite their work ethic was the discouragement of their knowledge and skills from their native countries being overlooked and demeaned considering their credentials were deemed not sufficient. The implicit message that Canada is sending to countries such as those of majority Black countries is that Western knowledge and education is superior to that of other countries outside of the Western Hemisphere.

Jordon suggests that anyone who is not Black has more of an advantage or opportunity to advance further in their careers, specifically those who are White or of East or South Asian descent. Pon (2005) describes what the participants have experienced as 'worthy citizenship' by stating that: "whites are situated on one extreme as the paragon of worthy citizenry and Asians are in the middle, closer to whites; while blacks are placed at the other extreme of non-worthy citizenry" (p. 126). What appears to be understood by both her and Duke is that Black people's identity continues to remain inseparable from that of labour and are therefore perceived to remain at the bottom of the employment hierarchy. We can also see through Jordon's stories, for example, she was a part of this narrative surrounding Blackness that we are not afforded the luxury of taking days off or receiving breaks despite experiencing family and personal turmoil 
outside of work. We can see that this narrative has perpetuated throughout time as we were still expected to work during slavery after having our children snatched from us, spouses killed, receiving no adequate food or compensation for our work and working amongst the worse conditions. It appeared that Jordon's supervisor did not feel that she required the time to grieve, let alone mourn her family member because work superseded her emotional and mental health. The same notion could be applied to Duke who was not afforded the opportunity to pursue education because it appeared that to support his education endeavours meant supporting his career advancement and intellectuality. We can see however that their protective factors that prevented them from giving up was their comradery with other Afro-Caribbean peers who helped them obtain work due to the relatability of the struggle against racism.

\section{No Resources, No Safety Net}

When the participants spoke about their reliance on their precarious work due to their credentials and work experience from their native country not being recognized, this reliance demonstrated that they are already placed at a disadvantage upon arrival in Canada. They were neither informed nor assisted by employers to receive assistance to gain resources to support their career development, rather were disposed of when seasonal or temporary work terminated. Although they were among other ethnic groups who were also immigrants, the detrimental narratives surrounding Black people appeared to place them at a disadvantage of being perceived as needing help as well as not being worthy of investing in. What is problematic, more than likely stemming from the unresolved conditioning from slavery is that those of Afro-Caribbean descent rarely ever complain to their White supervisors about the challenging conditions in which they are forced to work. Hence, anti-Black racism continues to insidiously operate by 
believing that Afro-Caribbean people understand their place in the employment sector and society overall.

Many Afro-Caribbean immigrants, such as the participants and any immigrant, come to Canada with very few resources and safety net; hence they are constantly in survival mode. Namely, they obtain any job they can secure with the intention of using it to fund their studies or provide as a foundation as they pursue opening a business or their initial field they specialized in back in their native country. The problem lies in the fact that this temporary, typically lowpaying job does not provide enough for them to pursue these ventures and they end up being stuck in this cycle of precarious work, consequently leading to less time being allotted to pursuing their dream, spending time with their families and more time allotted to surviving.

\section{CONCLUSION}

Toronto is now in a position where they seek to rectify past wrongs against Black people and address the inequities that are experienced by people of African descent (City of Toronto, 2019). To work towards this goal, their aim in their anti- Black racism action plan is to create initiatives to address each of the five main areas of concern: employment and entrepreneurship, supporting Black not-for-profit organizations, anti-Black racism in workplace institutions, children and youth development, and anti-Black racism in the customer service industry (City of Toronto, 2019).

With respect to employment, however, I argue that the action plan further perpetuates racism against African and Caribbean people. I argue this based on the fact that when employment is discussed for the group, it is typically centered on job placements and temporary 
positions at a low pay scale with the option of government income support programs, none of which provide tangible room for advancement much less wage increase and stability. Instead, there should be more effort surrounding the promotion of skills development whether practical or analytical (i.e. plumbing, engineering, or medicine). I strongly recommend that the City of Toronto consider the recommendations of the participants in order to effectively address and discuss the needed change in policies around education and the way it intertwines with the experience of employment for Afro-Caribbean immigrants.

If the action plan that the City of Toronto created is to be successfully implemented to confront anti-Black racism at every level of government, then the City needs to be more clear in why adults and seniors are not being directly targeted and implemented into the initiative. The City's initiative must also undergo a transparent and critical review of the work they have started and the work that they have ahead of them.

In conclusion, the Toronto Action Plan to Confront Anti-Black Racism needs to make a difference in employment policies, career and employment stability or wage increase that recognizes the forty-two years' worth of data collected on Afro-Caribbean people. Hence, as an effect, stability would then go to correct many other issues that are being faced by AfroCaribbean people, like dependency on the Ontario Works system and continuous run-ins with the justice system, as well as homelessness and all of the other social ailments that come with poverty (Meerai, Abdillahi, \& Poole, 2016). It is important that the City of Toronto adopt a long-term initiative that will address and respond to the injustice and inequity that is faced by Black women, men, youth, and children of Afro-Caribbean descent. 


\section{REFERENCES:}

Baskin, C. (2016). Starting at the beginning. In Baskin, C. Strong helpers' teachings. Toronto, Canada: Canadian Scholar's Press.

Bell, D. A. (1980). Brown v. board of education and the interest-convergence dilemma. Harvard Law Review, 93(3), 523-527.

Block, S., \& Galabuzi, G. (2018). Persistent inequality Ontario's colour-coded labour market (pp. 1-19). Toronto: Canadian Centre for Policy Alternatives.'

Burt, G., Sedra, M., Headley, B., Hernandez-Ramdwar, C., Seepersad, R. \& Wortley, S. (2016). Deportation, circular migration and organized crime: Jamaica case study. (Report No. PS18-32/1-2016E-PDF). Ottawa, ON: Research Division, Public Safety Canada

Clarke, J., Pon, G., Benjamin, A., \& Bailey, A. (2015). Ethnicity, race, oppression and social work: The Canadian case. The International Encyclopedia of Social and Behavioural Sciences, $2^{\text {nd }}$ ed., 8: 152-156.City of Toronto. (2017). Anti-black racism partnership \& accountability circle. Toronto. Retrieved from https://www.toronto.ca/legdocs/mmis/2017/ex/bgrd/backgroundfile-109129.pdf

City of Toronto. (2017). Attachment A: Anti-black racism partnership \& accountability circle. Toronto. Retrieved from https://www.toronto.ca/legdocs/mmis/2017/ex/bgrd/backgroundfile-109127.pdf

City of Toronto. (2017). Attachment B: Anti-black racism partnership \& accountability circle. Toronto. Retrieved from https://www.toronto.ca/legdocs/mmis/2017/ex/bgrd/backgroundfile-104832.pdf

City of Toronto. (2017). Attachment C: Intervention strategies. Toronto. Retrieved from https://www.toronto.ca/legdocs/mmis/2017/ex/bgrd/backgroundfile-104833.pdf 
City of Toronto. (2017). Attachment E: 2017 Work plan. Toronto. Retrieved from https://www.toronto.ca/legdocs/mmis/2017/ex/bgrd/backgroundfile-104853.pdf

City of Toronto. (2017). A report for action: The interim Toronto action plan to confront antiblack racism. Toronto. Retrieved from https://www.toronto.ca/legdocs/mmis/2017/ex/bgrd/backgroundfile-104623.pdf

City of Toronto. (2020). Tracking status; City counsel decision, tracking status; City counsel decision (2017). Toronto. Retrieved from City of Toronto. (April 30, 2020) Toronto Action Plan to Confront Anti-Black Racism; 2018 Work plan priorities (2018). Retrieved from https://www.toronto.ca/legdocs/mmis/2017/ex/bgrd/backgroundfile109128.pdf

City of Toronto. (2017). Tracking status; The interim Toronto Action Plan to Confront AntiBlack Racism Committee decision. Toronto. Retrieved from http://app.toronto.ca/tmmis/viewAgendaItemHistory.do?item=2017.EX26.5

City of Toronto. (2018) Toronto Action Plan to Confront Anti-Black Racism; 2018 Work plan priorities (2018). Retrieved from https://www.toronto.ca/legdocs/mmis/2017/ex/bgrd/backgroundfile-109128.pdf

City of Toronto. (2019). Update on Toronto Action Plan to Confront Anti-Black Racism. Retrieved from https://www.toronto.ca/legdocs/mmis/2019/ec/bgrd/backgroundfile134609.pdf

Ciupa, E.C. (2014). Experiences of Rexdale youth (Unpublished master's thesis). Ryerson University, Toronto, Ontario.

Creswell, J. W. (2013). Qualitative inquiry and research design: Choosing among five traditions. Thousand Oaks, CA: Sage. 
Delgado, R., \& Stefancic, J. (2017). Introduction and Hallmark critical race theory themes. In Critical race theory: An introduction. NYU Press. (pp. 1-17).

Denzin, N. (2016). Ryersonca. Retrieved 15 October, 2019, from https://journals-sagepubcom.ezproxy.lib.ryerson.ca/doi/full/10.1177/1077800416681864\#

Fanon, F. (2008 [1952]). Black skin white masks. New York, NY: Grove Press.

Frank, K. (2013). Immigrant employment success in Canada: Examining the rate of obtaining a job match. International Migration Review, 47(1), 76-105. https://doi.org/10.1111/imre.12014

Greenberg, D. (2016). Ryersonian.ca. Retrieved 15 October, 2019, from https://ryersonian.ca/ryerson-study-shows-temporary-work-is-a-public-health-crisis/

Greenidge, W. L., \& Daire, A. P. (2010). The relationship between emotional openness and the attitudes towards seeking professional counseling of English-speaking Caribbean college students. International Journal for the Advancement of Counselling, 32(3), 191201. doi:10.1007/s10447-010-9100-6

Hackett, V. (2019). African Caribbean presence: Decolonizing social work education 2019. Intersectionalities: A Global Journal of Social Work Analysis, Research, Polity, And Practice, 7(1), 105-125. Retrieved from https://journals.library.mun.ca/ojs/index.php/IJ/article/view/2160/1715

Iftikar, J. S., \& Museus, S. D. (2018). On the utility of Asian critical (AsianCrit) theory in the field of education. International Journal of Qualitative Studies in Education, 31(10), 935-949 
Kumsa, M., Kuwee, M., McCarthy, M., Oba, F. \& Gaasim, S. (2014). The contours of antiblack racism: Engaging anti-oppression from embodied spaces. CAOS: The Journal of Critical Anti-Oppressive Social Inquiry, 1, (21-38). Retrieved from http://caos.library.ryerson.ca/index.php/caos/article/view/6/2

Landson-Billings, G. (2000). Handbook of qualitative research. Thousand Oaks, CA: Sage Publications. (pp. 257-277).

Maiter, S., Joseph, A. J. (2017). Researching racism: The colour of face value, challenges and opportunities. The British Journal of Social Work, 47(3), 755-772, https://doi.org/10.1093/bjsw/bcw052

Maynard, R. (2017). Devaluing black life, demonizing black bodies: Antiblackness from slavery to segregation. In Policing black lives: State violence in Canada from slavery to the present. Fernwood Publishing. (p.17-49).

Meerai, S., Abdillahi, I., \& Poole, J. (2016). An introduction to anti-black sanism. Intersectionalities: A Global Journal of Social Work Analysis, Research, Polity, And Practice, 5(3), 18-35. Retrieved from https://journals.library.mun.ca/ojs/index.php/IJ/article/view/1682/1328

McDonald, J. T., \& Worswick, C. (1998). The earnings of immigrant men in Canada: Job tenure, cohort, and macroeconomic conditions. ILR Review, 51(3), 465-482. https://doi.org/10.1177/001979399805100306

McDonald, J., \& Worswick, C. (1997). Unemployment incidence of immigrant men in Canada. Canadian Public Policy / Analyse De Politiques, 23(4), 353-373. doi: $10.2307 / 3552069$ 
Neuman, W. L. (2006). Social research methods: Qualitative and quantitative approaches. Boston, MA: Pearson. (pp. 90-122).

Ng, W., Sundar, A., Poole, J., Karpoche, B., Abdillahi, I., Arat-Koc, S., ...\& Galabuzi, G. (n.d.). A public health crisis in the making- final (1) (1).pdf. Retrieved May 5, 2020, from https://drive.google.com/file/d/0B7HYn4lq0ns4RINiZHJGYjhKaXc/view

O’Connell, A. J. (2013). The deserving and non-deserving races: Colonial intersections of social welfare history in Ontario.

Patterson, O. (1982). Slavery and social death: A comparative study. Retrieved from https://hdl-handle-net.ezproxy.lib.ryerson.ca/2027/heb.03237.

Phillips, D., \& Pon, G. (2018). Anti-black racism, bio-power, and governmentality:

Deconstructing the suffering of black families involved with child welfare. Journal of Law and Social Policy, $28(1 \& 2), 84$. Retrieved from

https://digitalcommons.osgoode.yorku.ca/cgi/viewcontent.cgi?article=1298\&context=jls $\mathrm{p}$

Picot, G. (2004). The deteriorating economic welfare of Canadian immigrants. Canadian Journal of Urban Research, 13(1), 25-45. Retrieved March 31, 2020, from $\underline{\text { www.jstor.org/stable/44320794 }}$

Pon, G. (2005). Anti-racism in the cosmopolis: Race, class, and gender in the lives of elite Chinese Canadian women. Social Justice 32(4): 161-179.

Brown, L., \& Strega, S (2015). Research as resistance: Revisiting critical, Indigenous and antioppressive approaches. 2nd ed. Toronto: Canadian Scholars' Press, (pp. 17-42).

Powell, K., \& Takayoshi, P. (2003). Accepting roles created for us: The ethics of reciprocity. College Composition and Communication, 54(3), 394-422. doi:10.2307/3594171 
Ray, V. E., Randolph, A., Underhill, M., \& Luke, D. (2017). Critical race theory, Afropessimism, and racial progress narratives. Sociology of Race and Ethnicity, 3 (2), 147155.

Reitz, J.G. Immigrant employment success in Canada, Part II: Understanding the decline. International Migration \& Integration 8, 37-62 (2007). https://doi.org/10.1007/s12134-007-0002-3

Reitz, J.G. (2007). Immigrant employment success in Canada, Part I: Individual and contextual causes. International Migration \& Integration 8, 11-36 (2007). https://doi.org/10.1007/s12134-007-0001-4

Solorzano, D. G., \& Yosso, T. J. (2002). Critical race methodology: Counter-storytelling as an analytical framework for education research. Qualitative Inquiry, 8(1), 23-44. doi:10.1177/107780040200800103

Tuck, E., \& Yang, K. W. (2012). Decolonization is not a metaphor. Decolonization: Indigeneity, education and society. (p.1-40). https://www.google.com/search?client=safari\&rls=en\&q=tupac+dear+mama+lyrics\&ie $=\underline{\mathrm{UTF}}-8 \&$ oe $=\mathrm{UTF}-8$ 
Appendix A

\section{Recruitment Flyer}

\section{Career Advancement \& The Experiences of Black Immigrants In Ontario}

- Have you worked in the Canadian employment system in Ontario?

- Are you a Black immigrant who would like to share your employment experience in Ontario?

If you have answered yes to any of these questions you may qualify for this study. Participants must speak, write and understand English as there will be no interpreter. This study will allow me to hear 3 (three) participants about their opportunity for career advancement in their current or past careers/jobs. The purpose is to assess what barriers, struggles or limitation there are to career advancement in Ontario for Black Immigrants. It will be one interview per each participant via Skype/Zoom or over the phone. I am open to hear voices from anywhere in Ontario.

\section{What can you expect:}

- The interview will last up to 2 hours

- All interviews will be held at an agreed time and date where to ensure confidentiality

- Participants audio recording will be transcribed, and data can/will be used in study.

- Participant will receive a copy of the research transcript to ensure accuracy of participants experience once completed.

\section{Purpose:}

To hear the experiences about career advancement for black immigrants who live in Ontario

\section{Compensation:}

There will be no compensation for participation

\section{For more information please contact:}

Kimberly Coleman-Bryan, MSW Candidate

School of Social Work, Ryerson University, Toronto

K1coleman@ ryerson.ca

This study has been approved by the Ryerson research ethics board (REB protocol number: 2020-034) And is being conducted by a graduate student as a requirement for program Completion. Research supervisor can be reached at g2pon@ryerson.ca or by telephone at 416979-5000 ext.4786 


\section{Recruitment Email Script}

RE: Career Advancement \& The Experiences of Black Immigrants In Ontario

$\mathrm{Hi}$, my name is Kimberly Coleman-Bryan; I am currently completing a Master of Social Work degree at Ryerson University. I am in the process of recruiting participants for a small study on their experience in career advancement as black immigrants who have worked and lived Ontario. This research is required to complete my Master of Social Work Degree. The process will be supervised by Gordon Pon, Associate Professor, School of Social Work at Ryerson University, Toronto, g2pon@ryerson.ca, 416-979-5000 ext. 4786.

- Have you worked in the Canadian employment system in Ontario?

- Are you a Black immigrant who would like to share your employment experience in Ontario?

If you have answered yes to any of these questions you may qualify for this study. Participants must speak, write and understand English as there will be no interpreter. This study will allow me to hear the various voices of participants about their opportunity for career advancement in their current or past careers/jobs. The purpose is to assess what barriers, struggles or limitation there are to career advancement in Ontario for Black Immigrants. It will be one interview per each participant via Skype/Zoom or over the phone. There will be no compensation for participation.

\section{What can you expect:}

- The interview will last up to 2 hours

- All interviews will be held at an agreed time and date where to ensure confidentiality

- Participants audio recording will be transcribed, and data can/will be used in study.

- Participant will receive a copy of the research transcript to ensure accuracy of participants experience once completed.

\section{For more information please contact:}

Kimberly Coleman-Bryan, MSW Candidate

School of Social Work, Ryerson university, Toronto

K1coleman@ ryerson.ca

This research has been reviewed and approved by the Ryerson University Research Ethics Board (REB protocol number: 2020-034). If you are interested and would like to volunteer, please reply to this email k1coleman@ryerson.ca and leave a detailed email with your name, phone number or email and best time to contact you and I will respond to your email as soon as possible.

Sincerely,

Kimberly Coleman-Bryan

Master of Social Work Candidate, Ryerson University 
Appendix B

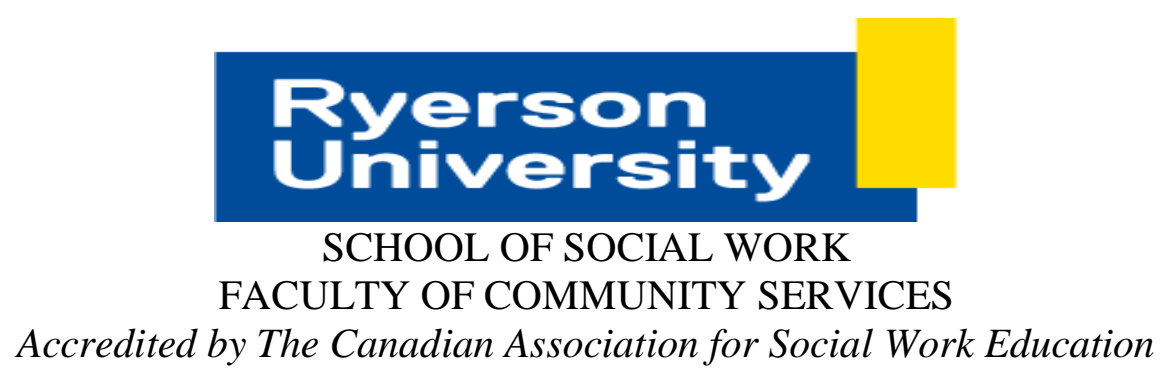

Consent Form

You are being invited to participate in a research study. Please read this consent form so that you understand what your participation will involve. Before you consent to participate, please ask any questions to be sure you understand what your participation will involve.

\section{Permanent Black Immigrants' Experiences of Working in Ontario}

\section{INVESTIGATORS:}

This research study is being conducted by Kimberly Coleman-Bryan, a graduate student in the Master of Social Work Program at Ryerson University under the direct supervision of Gordon Pon, Associate Professor, School of Social Work at Ryerson University, Toronto.

If you have any questions or concerns about the research, please feel free to contact Kimberly Coleman-Bryan by email at kimberly.coleman@ryerson.ca

\section{PURPOSE OF THE STUDY:}

The purpose of this study is to hear the experiences of Blacks in Canada who has firsthand knowledge about the employment industry through their own personal employment. For this study 3 individuals will be interviewed within Ontario. No interpreters will be available so all participants must speak, write and understand English.

The goal of this study is to understand what career advancement looks like for the Black individuals in Ontario. The goal is to understand challenges, successes, as well as obstacles and outcomes for Blacks who have been employed in Ontario. There are three purposes for this study and the information collected, data stored, transcription and produced from Participants interviews will be used to further the goal of the study. The first purpose is that the results of this research will contribute to a major research paper as a requirement to complete my degree at Ryerson University, School of Social Work. The second is that the data might also be used for publication in a peer-reviewed journal. The third purpose is that the information collected can be used to assist in employment policy change.

\section{WHAT YOU CAN EXPECT:}

Each volunteer that participates in this study will need to complete and/or expect the following:

- An email or phone call from me to answer questions prior to study.

- An email from me with consent form attached. 
- If you choose to participate you must read through and sign this consent form.

- All recordings and documents will be kept in a secure password encrypted file.

- A meeting date and agreed upon time will be selected where privacy can be ensured

- The interview will be a one on one Skype meeting with audio-recorder up to 2 hours.

- I will ask questions about your employment experience in Ontario as a Black person.

- As investigator, I Kimberly Coleman-Bryan will transcribe each audio recording.

- Once transcribed you will be given 2 days to review and edit your transcriptions.

- A final copy of the research paper can be sent to you once fully completed and finalized.

Some of the interview questions that you will be asked are:

- How long have you worked in Ontario?

- What are your experiences of working in Ontario?

- What types of career development training have your employers offered you?

- What have your experiences around opportunities for career advancement been like?

- Have you experienced any barriers to career advancement?

\section{You can decline answering any question that is asked}

\section{POTENTIAL BENEFITS:}

Participating in this study can provide potential benefits in the following area:

- The data collected used can contribute to existing literature on topic

\section{WHAT ARE THE POTENTIAL RISKS TO YOU AS A PARTICIPANT:}

You might receive discomfort based on discussion or length of interview. There is little to no risk in this study. To limit, reduce and/or prevent risk to participant I will advise that you can withdraw, stop or pause the interview at any time. If you decide to withdraw after July 31, 2020 all data collected from you can/will be used in the study. All data collected (audio recordings and personal data) will be deleted from my secure password protected file safe after final submission no later than August 2020. During the editing process you can remove and/or change information collected from your interview. Also, there is a limit to what can be kept confidential as I have an ethical responsibility of "duty to report "child abuse and/or neglect and risk of harm to yourself or others. Before the interview begins, we will have a discussion about the consent form as well as, privacy, self-harm, harm of others and my duty to report. This will give you the opportunity to ask any questions that you may have. These question however, can also be asked at any time during or after the interview.

\section{PRIVACY AND CONFIDENTIALITY:}

Your name and identity will remain confidential unless you want your real name in the research paper. If you prefer your real name to be used in the published material, please provide a signature under "CONFIRMATION OF AGREEMENT" section on the last page of this consent form to indicate your preference.

Any information provided by you will only be viewed by me, the investigator (Kimberly Coleman-Bryan), and if required, my supervisor (Gordon Pon); however, no identifying information will be shared. The data collected from the interviews will be audio-recorded and transcribed. Audio-recordings will be deleted once transcribed. All identifying information will 
be removed from transcripts and pseudonyms will be used in the place of your name to ensure confidentiality, unless you request for your real name to be used in the study. Transcripts and audio-recordings will be password protected. I will store the data until the research is completed in a file only I have access to. Consents will be kept separate from participants audio, and transcribed material which will be password protected and hard copies will be placed under file safe, lock and key and only accessible to myself (researcher) and no one else. I will hand in the final research paper to Ryerson University, no later than August 2020. You will have an opportunity to review and edit the transcript and draft copy of the research paper. You can be provided with a copy of the final paper delivered by the method of your preference via email.

Identifying information will not be accessible by any other parties except when required by law, such as when there are reasonable suspicions of child abuse and/or neglect or risk of harm.

\section{INCENTIVES AND COST FOR PARTICIPATION:}

There is no incentive reimbursements of any costs for participation.

\section{VOLUNTARY PARTICIPATION AND WITHDRAWAL:}

Your participation in this study is on a voluntary basis. You can ask questions pertaining to the study at any time. You can withdraw, pause or decline answering any question during the interview. You will have an opportunity to edit the transcription of the audio recording of our interview. Any data collected can/will be used for study up until August 2020 if not requested to be edited or removed. After, August 2020 your data cannot be removed from the study as it would have already been included in the final paper. Final copy of MRP can be access by participants through RULA digital repository. Involvement in this study will not influence your future relations with Ryerson University, Study Supervisor Gordon Pon or the investigator Kimberly Coleman-Bryan.

\section{QUESTIONS ABOUT THE STUDY:}

If you have any questions about the research now, please do not hesitate to ask via email. However, if you have questions after the research has been completed you may contact:

Principal Investigator: Kimberly Coleman-Bryan - kimberly.coleman@ ryerson.ca Study Supervisor: Gordon Pon - g2pon@ryerson.ca or 416-979-5000 ext. 4786

This study has been reviewed by the Ryerson University Research Ethics Board (REB protocol number: 2020-034). If you have any questions regarding your rights as a research participant in this study, please contact:

Research Ethics Board

c/o Office of the Vice President, Research and Innovation

Ryerson University

350 Victoria Street

Toronto, ON M5B 2K3

416-979-5042

rebchair@ryerson.ca 


\section{Permanent Black Immigrants' Experiences of Working in Ontario}

\section{CONFIRMATION OF AGREEMENT:}

Your signature below indicates that you have read the information in this agreement and have had a chance to ask questions about the study. Your signature indicates that you agree to participate in the study and have been told that you can change your mind and withdraw your consent to participate at any time. You have been given a copy of this agreement. You have been told that by signing this consent form you are not giving up any of your legal rights.

Name of Participant (please print)

Signature of Participant

Date

I agree to have this interview audio-recorded and later transcribed for the purposes of this study. I understand how these recordings and transcribed materials will be stored in a secure and password protected place and destroyed once study is completed.

Signature of Participant

Date

I would prefer to have my REAL NAME used in the published materials of this study.

Signature of Participant

Date

Please indicate with your signature below if you give your consent to be contacted regarding the study results:

I would like to review my transcript via email (you will have 2 days to review and edit your transcript once transcribed)

I would like a copy of this research to review before the final submission via email (you will have 2 days to review, edit and provide feedback)

I would like a copy of this research, when it is completed via email

Signature of Participant

Date 


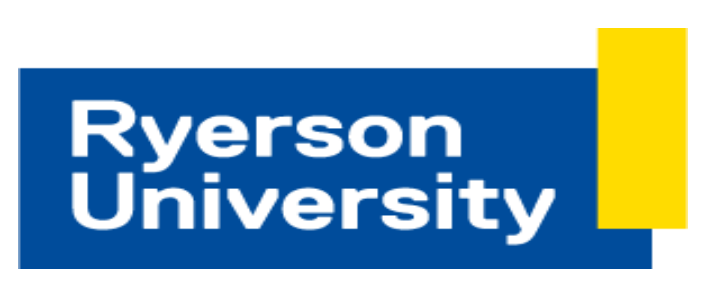

\section{Interview Guide}

Experiences of Black Immigrants who have lived and worked Ontario

\section{Introduction:}

Hey thanks for coming to see me. My name is Kimberly Coleman-Bryan and thank you for your voluntary participation in this study. This interview can last up to $2 \mathrm{hrs}$. Please be aware that you can decline to answer any question or withdraw from the study at any time with no penalty. (I will then begin to discuss consent, confidentiality, duty to report and details about the study as well as structure of interview like breaks, turning off audio recording, discomfort, triggers, services that can provide support if/when needed and process that takes place if participation is revoked by Participant). You can ask me questions at any time in regard to consent, confidentiality, duty to report. This study and all information collected will be transcribed and once transcribed it can/will be used in research. Are you ready to continue if not is there any further detail or information I can provide or clarify for you?

\section{Central Research Question:}

What are the employment experiences of black immigrants around career advancement in Ontario? Explored will be cultural, historical, political and socio-economic factors that influence career advancement for black immigrants in Ontario.

\section{Opening Questions:}

Can you tell me a little about yourself (social location, cultural, socio-political and socioeconomic overview)?

What/Who brought you to Canada, how long have you been in Canada/Ontario?

Do you have family here or abroad (who are they/are they dependants)?

What types of employment, if any, did you have abroad?

What types of employment did you have in Ontario?

What level of education did you have abroad and in Canada?

Did your level of education abroad get recognized in Canada?

Topic Specific Questions (questions will be asked for each job/career that participant shares):

How long have you worked in Ontario?

What are your experiences of working in Ontario?

What types of career development training have your employers offered you?

What have your experiences around opportunities for career advancement been like?

Have you experienced any barriers to career advancement? 


\section{Follow-up Questions:}

Are there any changes that took place in your life that required you to make more income?

Have you applied for positions based on your experience or applied based on income?

Have you ever turned down a position due to life circumstances (what kind and why)?

Describe a situation you were more suited for a position but did not receive it?

What is the longest time that you have held a paying position?

Did you have the qualifications for the position?

What made you leave the position

What have you done to advance yourself at that place of employment?

What contributed to you getting/not getting the raise or promotion

What internal or external supports were in place to assist you with your job

\section{Context Question:}

Did you feel that places where you were employed were underrepresented or prepared to support your ethnic, cultural or immigrant needs/differences?

\section{Potential Probing Question:}

Do you feel like your employed positions created opportunity for growth for back immigrants?

Do you feel that there was extra pressure to work as hard or harder to get paid or lose your job? If yes who implied it or what made you feel/think that?

If you could make changes to the employment system in Ontario what would it be and why?

\section{Concluding Remarks}

I appreciate you taking the time to share your experiences with me today. Do you have any questions for me or any additional information you would like to add that I have not asked or properly covered? If I have follow up questions can I request a date and time to speak with you via email prior to August 2020. Also, if you have anything you would like to add after this interview I can be reached via email and we can set up a date and time to proceed. Once again thank you very much of your participation. 